\title{
CrimRxiv
}

\section{Thinking About Criminology}

\section{Simon Holdaway}

Published on: Jun 04, 1998

DOI: 10.21428/cb6ab371.2dd9b605

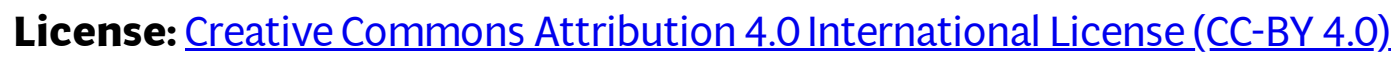


